\title{
The 2016 EU Referendum: Explaining support for Brexit among would-be British MPs
}

\author{
Dr Siim Trumm \\ University of Nottingham (School of Politics and International Relations) \\ siim.trumm@nottingham.ac.uk \\ Dr Caitlin Milazzo \\ University of Nottingham (School of Politics and International Relations) \\ caitlin.milazzo@nottingham.ac.uk \\ Dr Joshua Townsley \\ University of Nottingham (School of Politics and International Relations) \\ joshua.townsley@nottingham.ac.uk
}

\begin{abstract}
The outcome of the 2016 referendum on European Union membership took many by surprise and has continued to define the political discourse in Britain. Despite there being a growing body of research focused on explaining how voters cast their ballot, we still know little about what motivated our politicians to do the same. In this article, we draw on individual-level survey data from the British Representation Study to explore support for Brexit among parliamentary candidates who stood at the 2017 general election. We find that candidates' political views on immigration and democracy were key determinants of their decision to vote Leave. In addition, more optimistic views of how Brexit was expected to impact British economy and democracy are associated with greater likelihood of voting Leave. These findings highlight that, while politicians were less likely than voters to support Brexit overall, their motivations for doing so were quite similar. Interestingly, however, we also find that candidates contesting constituencies with higher Leave support were no more likely to vote for Brexit themselves. Taken together, these findings have important implications for elite representation of voters' policy preferences on the issue of Brexit.
\end{abstract}

Keywords: Brexit, parliamentary candidates, immigration, democracy, economy

Acknowledgements: This research is funded by the Economic and Social Research Council grant ES/R003785/1.

Name of journal: Political Studies

Date of acceptance: 17/01/2020 


\section{Introduction}

The 2016 referendum on the European Union (EU) membership marked a significant juncture in the history of the United Kingdom (UK). The country voted to leave the EU, indicating that it wanted to end a membership that spanned over four decades. The vote set into motion developments that have been shaping the British political landscape and discourse ever since.

The unexpected result of the EU referendum raised the obvious question of who supported Brexit on June 23rd, and unsurprisingly, research on the drivers of support for Leave and Remain has become a minor industry since 2016. As a result, we now have an extensive body of literature examining how voters' personal characteristics and political views relate to their vote choice (e.g., Clarke et al. 2017; Goodwin and Milazzo 2017; Hobolt 2016; Vasilopoulou 2016) and how the strength of the Leave vote varies across communities (e.g., Goodwin and Heath 2016; Matti and Zhou 2017). While the literature of voters is now well-established, the study of support for Brexit among political elites remains in its infancy. There is an emerging literature focusing on which politicians cast their ballot for Leave in 2016 (Heppell et al. 2017a; Lynch and Whitaker 2018; Moore 2018), but to date, the focus of these studies has largely been limited to the members of the parliamentary Conservative Party.

In this paper, we expand the scope of the investigation to explore the drivers of support for Brexit among political elites more generally. In doing so, we hope to address the following questions: What influenced our 'political class' to support, or oppose, Brexit? Are the factors explaining Leave support among politicians and voters similar, or not? These questions are important because they help us better understand the mind-set of the political actors who play a vital role in the democratic process. Exploring the motivations of political elites on the key issue of our generation provides valuable insights into the supply side of the representation divide at this critical juncture of British politics. It gives voters clarity not only about what elites do, but also about how they form their choices. Moreover, politicians are often portrayed as being out of touch with voters. With respect to Brexit, this perception is grounded in fact - politicians were less likely to cast their ballot for Leave than voters. What we do not know, however, is whether this discrepancy was limited to vote choice, or whether there were more fundamental differences in how voters and elites formed their views. We consider this to be an empirical question, and we seek to shed further light on the drivers of elite support for Brexit, so that we may determine the extent to which elite motivations align with, or diverge from, what we already know about voters.

To answer these questions, we use survey data from the 2017 British Representation Study. We focus on candidates who stood at the 2017 British general election and examine how important the strength of Leave support in their constituency, as well as their personal characteristics and political attitudes 
were in shaping their support for, or opposition to, Brexit at the 2016 EU referendum. In doing so, this paper builds on the emerging body of literature on politicians' voting choice in June 2016 and furthers our understanding of what motivated our politicians to support Leave. The analysis reveals interesting patterns. We find that candidates' personal characteristics and the strength of the Leave sentiment in their constituency did not systematically influence their likelihood of voting for Leave. By contrast, candidates' views about immigration (its impact on Britain and its general importance), as well as their views on how democratic the EU is perceived to be, and what the Brexit effect is likely to be for the UK, are key drivers for their EU referendum vote choice. In addition, we find candidates' views on Europe to be quite stable - very few of them changed their mind in the year running up to the referendum. These findings touch upon some of the key debates and perceptions in British politics, and they provide further support for the prominent narrative that politicians are 'out of touch' with voters when it comes to their attitudes towards Brexit. That said, their key motivations for voting Leave are broadly in line with those among voters.

This article is organised as follows. In the next section, existing literature that is touched upon to guide our investigation is examined. We then outline our theoretical expectations, describe the data used, the operationalisation of the variables, and the empirical strategy. This is followed by the presentation of the findings. Finally, the paper concludes with a brief discussion of the implications that emerge from the empirical evidence.

\section{Who voted for Leave?}

The 2016 EU referendum - and its outcome - has fundamentally redefined the British political landscape and discourse. It is, therefore, unsurprising that there is now an extensive body of literature on who cast their ballot for Leave in 2016. A number of socio-demographic factors have been identified as helping us better understand why some voters cast their ballot for Leave, while others opted for Remain. Individual-level studies have shown that Leave support was higher among older voters (Henderson et al. 2017; Hobolt 2016), those with lower educational attainment (Goodwin and Milazzo 2017; Hobolt 2016; Vasilopoulou 2016), and those holding stronger national identities and weaker European ones (e.g., Curtice 2017; Goodwin and Milazzo 2017; Henderson et al. 2016; Hobolt 2016). ${ }^{1}$ These patterns are also found by aggregate-level studies that compare Leave support in regions with different demographic profile (e.g., Arnorsson and Zoega 2018; Goodwin and Heath 2016; Hanretty 2017; Johnston et al. 2018; Matti and Zhou 2017). ${ }^{2}$ The evidence about the relevance

\footnotetext{
${ }^{1}$ A notable exception is the recent study by Clarke et al. (2017) that did not find those factors to have influenced one's likelihood of voting Leave.

${ }^{2}$ Studies of geographical variation also find support for Brexit to be higher in areas that had experienced greater levels of economic decline prior to the EU referendum (Lee et al. 2018; MacLeod and Jones 2018). The recent ethnographic studies further highlight the relevance of the 'left out' sentiment in driving Leave vote in working
} 
of economic factors and gender is not as consistent. Some find that both traits had a significant effect on Leave support (Hobolt 2016), while others find a consistent significant effect only for one (Matti and Zhou 2017; Vasilopoulou 2016), and others for neither (Clarke et al 2017; Goodwin and Milazzo 2017). ${ }^{3}$

In addition to socio-demographics, voters' political profile has also been shown to influence their support for - or opposition to - Leave. For example, voters' general ideological stance on the conventional left-right spectrum correlates with their EU referendum vote choice, with more rightwing placement being associated with stronger likelihood of casting a Leave vote (Henderson et al. 2017; Vasilopoulou 2016). Policy concerns also matter. There is evidence that concerns related to the economy tended to drive support for Remain (Evans et al. 2016), while fears related to immigration led voters to support Leave (e.g., Goodwin and Milazzo 2017; Hobolt 2016; Vasilopoulou and Keith 2019). That said, evidence about whether actual exposure to immigration had strong effect on support for Brexit is mixed (Becker et al. 2017; Colantone and Stanig 2018; Goodwin and Heath 2016). Studies suggest that it is the perception of immigration, and not the experience with immigration, that was linked to the issue of Europe and drove support for Brexit (Curtice 2017; Ford and Goodwin 2017; Goodwin and Milazzo 2017). ${ }^{4}$ In addition, political attitudes are shown to relate to one's EU referendum vote choice. Leave support was higher among voters who hold more negative perceptions of the political system and how it works (Bromley-Davenport et al. 2018; Hobolt 2016; Vasilopoulou and Keith 2019), as well as the impact the EU membership has so far had on the UK (Hobolt 2016; Vasilopoulou 2016; Vasilopoulou and Wagner 2017), and who want greater national-level control over policy-making (Hobolt 2016). Finally, those who were more positive about the expected effect of Brexit are also more likely to have voted for Leave (e.g., Clarke et al. 2017; Curtice 2017; Hobolt 2016). In summary, a broad range of attitudes are seen to influence whether voters cast their ballot for Leave or Remain, ranging from their policy concerns to views on the state of democracy and the expected Brexit effect.

There is also an emerging body of literature that aims to explain Leave support specifically among our political elites. This body of evidence is, however, less extensive. ${ }^{5}$ Heppell et al. (2017a), Lynch and

class communities in East London and Nottinghamshire (Mckenzie 2017), the role of economic deprivation in Sunderland (Bromley-Davenport et al. 2018) and the closing of coal mines in Wales (Jones 2017).

${ }^{3}$ Hanretty (2017) finds significant effects for occupation type, but his study does not explore the potential effect associated with gender.

${ }^{4}$ The saliency of immigration as an issue that encouraged Leave support has been linked to the role of elitelevel actors. These include the British Eurosceptic press (Menon and Salter 2016) as well as the official 'Vote Leave' campaign which messaging focused largely on concerns over immigration and the need to 'take back control' of the UK's borders (Gamble 2018; Shaw et al. 2017).

${ }^{5}$ The existing literature on Euroscepticism in British political parties is of course rather extensive. For example, Heppell (2013) looks at Euroscepticism within the 2010 intake of Conservative MPs, Hertner and Keith (2017) examine the messaging of the Labour Party and the Liberal Democrats on Europe, and Tzelgov (2014) explores 
Whitaker (2018), and Moore (2018) examine Leave vote among the members of the parliamentary Conservative Party. They find that political attitudes, mainly social conservatism, played a key role in understanding their support for Leave, whereas the socio-demographic characteristics do not appear to have had a significant effect on the EU referendum vote choice of the Conservative MPs (Heppell et al. 2017a; Lynch and Whitaker 2018; Moore 2018). These studies build on a rich strand of research into the behaviour of British legislators. We know that British MPs are becoming more rebellious over time (e.g., Cowley 2005; Cowley and Stuart 2012; Norton 1975) and, therefore, are increasingly less likely to 'toe the party line' on big issues. Other studies show that social conservatism and Euroscepticism, rather than demographic characteristics, predict voting on issues such as spending on international aid (Heppell et al. 2017b) and party leadership elections (Jeffery et al. 2018).

Finally, there is some evidence that constituents' views on key issues can impact the voting behaviour of MPs. Analysing parliamentary divisions on abortion, studies have found that, while most MPs divide largely along partisan lines (Cowley and Stuart 2010), MPs who are representing socially conservative constituencies tend to vote along their constituents' preference (Baughman 2004). Similarly, there is some evidence that members of the parliamentary Conservative Party were more likely to vote Leave in 2016 if they represented constituencies with strong Leave sentiments (Lynch and Whitaker 2018; Moore 2018). Legislators can indeed be incentivised to break from party lines and vote in accordance with constituents' views, as doing so can be viewed favourably by voters (Campbell et al. 2016).

This body of literature is invaluable in providing insights into the role that various types of factors play in motivating political elites' behaviour, including on whether they would cast their ballot for Leave or Remain, but it still has limitations. On the one hand, the existing insights derive from a relatively narrow range of political spectrum. The focus on the members of the parliamentary Conservative Party is unsurprising as the European issue has had a major effect on the Conservative Party in recent times, but it does limit our understanding of which politicians voted for Leave. It is important to extend the range of politicians whose behaviour at the EU referendum is examined and build an understanding of Leave support that transcends any one party. Moreover, it is important to examine the EU referendum choices of both electorally successful and unsuccessful candidates. After all, parliamentary candidates - regardless of whether they are elected or not - represent the choices available to voters during an election. Understanding the behaviour of all candidates is critical because it provides key insights into representation, and sheds further light on how elites balance their own views with the views of those they seek to represent. On the other hand, the existing studies of

the voting behaviour of MPs on Europe between 1992 and 1997. This body of literature is invaluable in helping us understand the context that ultimately set the scene for the 2016 EU referendum, but it does not focus on how politicians ultimately voted in June 2016. 
elite support for Leave tend to look at the potential effects of a very limited range of political attitudes. The evidence from the voter side suggests that political attitudes played a critical role in determining how people voted at the EU referendum. Therefore, it is important to rely on a broader range of attitudes when describing the views of our politicians. One should also capture what their policy concerns are, how positive they are about the state of democracy in the EU, and what they perceive the Brexit effect to be to build a more nuanced understanding of what incentivised politicians to vote Leave in 2016.

\section{Expectations}

Our expectations follow the existing literature from the voter side. ${ }^{6}$ We expect support for Leave to be stronger among male candidates, those who are older, have an occupational background in manual work, were not sitting MPs at the time of the referendum, and who stand in constituencies with higher Leave vote. In terms of political views, stronger Leave support should be associated with concerns about immigration, but not the economy, scepticism about the way that democracy works in the EU, negative views about the economic and cultural effect that immigration has, and expectations that leaving the EU will have positive effects on British economy and democracy. Table 1 summarises these expectations.

\section{[TABLE 1 HERE]}

\section{Data and methods}

The theoretical expectations are evaluated using data from the 2017 British Representation Study. ${ }^{7}$ It is a survey of parliamentary candidates standing at the 2017 general election, including questions about their personal and political background as well as, crucially, political attitudes. The sample used includes 872 candidates (37\% response rate) from the Conservative Party, the Green Party, the Labour Party, and the Liberal Democrats. ${ }^{8}$ It is broadly representative of the full population of candidates on key characteristics such as partisanship, nation, and electoral performance. ${ }^{9}$

\footnotetext{
${ }^{6}$ There are data-related limitations that do not allow us to test for the potential effects of all socio-demographic factors. This includes, for example, education and identity.

${ }^{7}$ The 2017 British Representation Study is the latest in a long series of surveys of general election candidates in Britain. Data from these candidate studies have been used to study the representation of minorities (Sobolewska et al. 2018), electoral learning (Norris and Lovenduski 2004), candidate positioning (Buttice and Milazzo 2011), MPs' ethical attitudes (Allen 2008), etc. as they capture both candidates' personal and political profile.

${ }^{8}$ We exclude candidates from parties where no variation in the EU referendum vote choice existed. Partisanship predicted perfectly Remain vote for Plaid Cymru and the Scottish National Party candidates and Leave vote for the UK Independence Party candidates.

${ }^{9}$ Please see Appendix A for further information about the sample.
} 
There are key advantages in using survey data from the 2017 British Representation Study to examine Leave support among politicians. First, it is the most comprehensive recent survey of politicians that includes questions on their political views as well as background and covers multiple political parties. It allows us to evaluate the role that different types of factors played in encouraging the parliamentary candidates of different parties to vote for Leave versus Remain. Second, the survey captures the views of both successful and unsuccessful candidates. The former are of course more important in terms of policy-making and understanding the post-referendum developments in the House of Commons, but the interactions that voters have with the 'political class' more broadly also include the latter. Finally, the reliance on survey data allows for the examination of candidates' sincere, unbiased views. Unlike public statements of political positions, which are subject to scrutiny by parties and voters, survey responses are confidential, and candidates do not have to be concerned with what their party or voters might think of their views.

\section{Dependent variable}

The dependent variable in this study is Leave. It is a dichotomous indicator that distinguishes between candidates who voted Leave (coded 1) and Remain (coded 0) at the EU referendum. Those candidates who did not vote or could not recall how they voted are excluded from the analysis.

\section{Explanatory variables}

The evidence from voter side suggests that support for, and opposition to, Leave is multifaceted in its motivation. Therefore, this study incorporates different types of factors in its effort to explain support for Leave among politicians.

First, we account for elements of candidates' personal and political profile. Gender is operationalised as a dichotomous variable, with male candidates coded 1 and female candidates coded 2. Age is a continuous variable that describes how old respondents were at the time of the 2017 general election. Occupation distinguishes between candidates who describe their occupational background as manual work (coded 1) and those with a different occupational background (coded 0). Finally, we include an indicator incumbency that captures whether candidates were MPs at the time of the EU referendum (coded 1$)$ or not $(\operatorname{coded} 0)$.

Second, we capture the strength of Leave sentiment in candidates' constituency through Constituency vote. We do so by using the estimated Leave vote in parliamentary constituencies, developed by Chris Hanretty (2017a, 2017b), which ranges from 0 to 100 . Higher values correspond to stronger estimated Leave vote in the constituency where the candidate stood for election. 
Third, we include a range of factors that account for candidates' political views. We use two measures that tap into what policy areas candidates are concerned about. MIP immigration separates candidates who consider immigration-related issues as the most important problem facing the UK (coded 1) from those who do not (coded 0) and MIP economy separates candidates who believe that economic issues constitute the most important problem facing the UK (coded 1) from those who do not share this view (coded 0). EU democracy is included to capture how satisfied candidates are with the way democracy works in the EU. This indicator ranges from 1 'very satisfied' to 4 'not at all satisfied', as higher values correspond to greater disillusionment with the EU as an organisation. Moving on, we include two indicators that tap into candidates' views on the effect that immigration has on Britain.

Immigration (economy) describes what effect candidates believe immigration has on British economy, ranging from 1 'bad for economy' to 7 'good for economy'. Immigration (cultural) captures the effect candidates believe immigration has on Britain's cultural life, ranging also from 1 'undermines cultural life' to 7 'enriches cultural life'. The last two political attitudes included in the analysis relate to what candidates expect the consequences of leaving the EU to be. Brexit (economy) describes the expected Brexit effect with regards to big businesses leaving the UK, ranging from 1 'much less likely' to 5 'much more likely'. Brexit (democracy) describes what candidates expect the Brexit effect to be with regards to the UK Parliament increasing its power, ranging also from 1 'much less likely' to 5 'much more likely'.

Finally, the analysis controls for candidates' partisanship. Party distinguishes between candidates who ran under the labels of the Conservative Party (coded 1), the Green Party (coded 2), the Labour Party (coded 3), and the Liberal Democrats (coded 4). As highlighted earlier, parties where candidates were unanimous in their support for Leave or Remain are excluded from the analysis.

\section{Empirical strategy}

Given the dichotomous nature of the dependent variable, the potential effects of explanatory variables on candidates' decision to vote Leave are evaluated using a series of logistic regression models with robust standard errors. We run five models. The first four include only a certain sub-set of explanatory characteristics and the final model includes all explanatory characteristics.

\section{Elite support for Brexit}

We now turn to the empirical analysis to examine which factors had systematic effects on candidates' likelihood of casting their ballot for Leave in 2016. Table 2 presents the findings from the multivariate logistic regression models.

Note first that candidates' personal and political profile does not appear to have had systematic effect on their likelihood of voting Leave or Remain at the EU referendum. The effects associated with their 
gender, age, occupational background, and incumbency do not reach conventional levels of statistical significance in Model 2 where only this sub-set of explanatory variables is included alongside the party control, nor in Model 5 that includes the full set of explanatory variables. ${ }^{10}$ This is not to say that other personal characteristics associated with candidates' demographic profile and political experience had also no influence on their EU referendum vote choice, but the evidence presented here does not reveal significant effects for the four personal and political characteristics that are included in this analysis.

Moving on, we explore whether the strength of Leave sentiment in the constituency a candidate stood for election has an influence on her likelihood of casting a Leave ballot. It is reasonable to suggest that vote-seeking motivations encourage anyone thinking about running for an elected public office to rationally align their EU referendum position with public opinion in their constituency. ${ }^{11}$ The initial look at the evidence suggests that this might indeed be the case as the positive, and significant, coefficient of 0.03 for constituency vote in Model 3 indicates that candidates' likelihood of voting for Leave is higher in constituencies with stronger Leave sentiment. When controlling for the full set of explanatory characteristics (Model 5), this effect, while remaining in the expected direction, becomes insignificant. ${ }^{12}$ The estimates associated with constituency vote are rather uncertain and do not reveal a clear, and significant, link between candidates' and their constituents' likelihood of voting Leave. ${ }^{13}$

The evidence, however, is much clearer about the significant role that candidates' political views play in shaping their EU referendum vote choice. The effects associated with these characteristics are very consistent and robust across Models 4 and 5 where, respectively, a sub-set or all explanatory variables are included. First, candidates' attitudes towards the EU matter. The positive coefficient of 1.76 for $E U$ democracy in Model 5 shows that candidates who are more negative about how democracy works in the EU are also more likely to have cast their ballot for Leave. The drivers for Leave vote were not

\footnotetext{
${ }^{10}$ This non-finding is not entirely out of line with existing evidence. Whereas most studies of voters find at least some of their personal characteristics to influence support for Leave, these effects are generally not consistently present across all studies and they tend to be weaker than those associated with voters' political opinions (e.g., Clarke et al. 2017; Goodwin and Milazzo 2017; Hobolt 2016; Vasilopoulou 2016). Similarly, existing studies of the supply side find very little evidence that socio-economic characteristics had a systematic effect on the voting behaviour of the members of the parliamentary Conservative Party at the EU referendum (Heppell et al. 2017a; Lynch and Whitaker 2018; Moore 2018).

${ }^{11}$ There is in fact evidence that MPs' policy positions affect their electoral performance (Kam 2009) and are responsive to public opinion in their constituency (Baughman 2004; Hanretty et al. 2017).

12 The existing evidence from studies of the parliamentary Conservative Party also suggest that constituency Leave vote had a weaker than anticipated role in determining MPs' voting choice at the EU referendum. Lynch and Whitaker (2018) find it to have had a statistically significant effect on whether they voted Leave or not in some models but not all, and Moore (2018) finds other explanatory variables to have been more influential in shaping this decision.

${ }^{13}$ This is in line with the broader narrative of many politicians being 'out of touch' with their constituents on the issue of Europe. Not only were MPs less likely to support Leave than voters in June 2016, there are a significant number of Remain-voting MPs in Leave-dominating constituencies and, albeit many fewer, Leavevoting MPs in Remain-dominating constituencies (Hanretty 2017b; PoliticsHome 2016).
} 
limited to utilitarian concerns or policy-related views. They also include the critical evaluation of the EU as an organisation and how democratic it is perceived to be in its working. ${ }^{14}$ Second, immigrationrelated views stand out. The positive coefficient of 3.28 for MIP immigration suggests that candidates whose primary concern for Britain related to immigration are more likely to vote Leave than those who do not share that view, and the negative coefficient of -0.46 for immigration (cultural) shows that more positive perceptions of the effect that immigration has on cultural life in Britain are associated with lower likelihood of voting for Leave. ${ }^{15}$ Finally, both factors related to the utilitarian evaluations associated with the perceived Brexit effect stand out as significant in understanding support for Leave. The negative coefficient of -0.63 for Brexit (economy) shows that candidates who are more likely to believe that big businesses will leave the UK due to Brexit are less likely to have voted for Leave, and the positive coefficient of 1.11 for Brexit (democracy) shows that candidates who are more likely to believe that the UK Parliament will become more powerful after Brexit are more likely to have voted for Leave. The perceived Brexit effect was clearly an important factor in candidates' decision to opt for a Leave or Remain vote at the EU referendum.

As we would expect, the estimates regarding partisanship indicate that Conservative Party candidates were more likely to vote Leave than those of the Green Party, Labour Party, and Liberal Democrats. However, it is important to note that the estimates for partisanship effects are statistically significant across all models only for the comparison of candidates from the Labour Party and the Conservative Party.

\section{[TABLE 2 HERE]}

To illustrate the real-world meaning of the findings and compare the effect sizes, Table 3 presents the predicted probabilities for candidates' likelihood of voting Leave. For each effect, the characteristic in question is allowed to vary, while others are held constant.

Note first that Leave support is low among candidates across the board. The probability of a Leave vote is strongest among candidates who consider immigration-related issues to be the most important problems facing the country (24\%). This is very much in line with what the Press Association survey of MPs found in early 2016, where 159 MPs claimed they would vote Leave (approximately 25\%), 480 claimed they would vote Remain, and 11 did not declare their voting intention (Full Fact 2019). ${ }^{16}$

\footnotetext{
${ }^{14}$ Evidence from the voter side is mixed about whether satisfaction with democracy in the EU played a role in encouraging Leave vote. Whereas Vasilopoulou (2016) does not find a significant link, Vasilopoulou and Keith (2019) find a significant effect in line with the evidence presented here.

15 This is in line with the evidence from the voter side (e.g., Arnorsson and Zoega 2018; Goodwin and Milazzo 2017; Vasilopoulou and Keith 2019).

${ }^{16}$ A very similar pattern was also found by PoliticsHome (2016) when examining the public statements of MPs.
} 
It is, however, significantly lower than the $51.8 \%$ of voters as a whole who cast their ballot for Leave. This lends further support to the prevalent 'out of touch' criticism that is increasingly levied against the 'political class' in Britain.

Next, we examine the effect sizes associated with the explanatory variables that had a significant effect on candidates' likelihood of voting Leave in Model 5 (Table 2). ${ }^{17}$ Interestingly, they do not vary substantially, with the strongest effect size being only 6 points higher than the weakest effect $(15.4 \%$ versus $9.4 \%$ ). This is noteworthy and does suggest some difference in how important the different characteristics are in shaping the narrative of who voted Leave, but it also implies that candidates' decision to support, or oppose, Leave was not determined by any one factor. In terms of the immigration-related attitudes, candidates who are most concerned with immigration-related issues are 15.4 points more likely to vote Leave than those who prioritise some other issue ( $24 \%$ versus $8.6 \%$ ), and those who believe that immigration undermines cultural life in Britain are 11.2 points more likely to vote Leave than those who think immigration enriches it (16.9\% versus 5.7\%). Attitudes towards the state of democracy in the EU also matter as those who are most positive about it are 13.8 points less likely to vote Leave than those what are most negative about it $(0.8 \%$ versus $14.6 \%)$. Finally, the utilitarian considerations about the expected Brexit effect play a role. Candidates who expect a positive economic effect are 9.4 points more likely to vote Leave than those who expect a negative one (15.1\% versus 5.7\%), and those who expect the UK Parliament to become stronger after Brexit are 13.3 points more likely to vote Leave than those who expect it to end up weaker (14.8\% versus $1.5 \%)$.

The evidence presented here suggests that the motivations for voting for Leave are diverse. There is no one or two factors that stand out as the key drivers for candidates' decision to cast their ballot for Leave or Remain. Instead, utilitarian concerns about the expected Brexit effect, policy considerations and political attitudes, as well as perceptions of the EU and how democratic it is, all played a role in incentivising candidates to cast their ballot for Leave or Remain.

\section{[TABLE 3 HERE]}

\section{Supplementary analysis}

The analysis above examined the role that different personal and political factors played in motivating the 2017 general election candidates to cast their vote for Leave at the EU referendum. Interestingly, we also have insight into what the EU referendum voting intentions of some of these candidates were

\footnotetext{
${ }^{17}$ All five effects are both statistically significant as well as substantively meaningful. There is no overlap in the 95\% confidence intervals around the predicted probabilities at the lowest and highest values of the explanatory variables.
} 
before the referendum. This evidence comes from the 2015 British Representation Study, which asked 2015 general election candidates about their EU referendum voting intention.

We know the pre-referendum voting intention and the actual voting choice for 442 candidates. Also, we know both for candidates of 781 parties in the same constituency. ${ }^{18}$ Whereas the former gives us a better understanding of how stable politicians' views on the EU referendum question are and whether the Leave and Remain campaigns were able to change the positions of many politicians, the latter tells us how common it was for parties to adopt candidates with different EU referendum positions in the very same constituency at the 2015 and 2017 general elections. These comparisons are summarised in Table 4.

Whereas polling evidence from voter side suggests that there was quite a bit of fluidity in the public opinion during the year prior to the EU referendum (What UK Thinks 2019), this does not seem to be the case among politicians. Only 12 (out of 442) candidates changed their mind, constituting as little as $2.7 \%$ of all candidates we have this information for. Seven candidates changed their vote from Remain to Leave and even fewer (five) moved from Leave to Remain. An overwhelming majority of candidates $(97.3 \%)$ remained unchanged in their vote choice. Unsurprisingly, the most popular option is for candidates who intended to vote Remain to indeed cast their ballot for Remain, which applies to $363(82.1 \%)$ of them, followed by $67(15.2 \%)$ candidates who intended to vote for Leave and who did indeed so. In other words, there were very few candidates who switched their voting choice in the run up to the EU referendum.

The lack of change in candidates' individual views is unsurprising, but one might expect to see more change when comparing the views of candidates whom parties picked to run as their candidates in specific constituencies in 2015 and 2017. After all, given the importance of Europe as an electoral issue at the 2017 general election, it would make sense for parties to pick candidates who are aligned with most voters in a given constituency in their support for Remain or Leave. This would suggest a notable number of shifts from Remain to Leave, with a smaller number of Leave to Remain shifts, as it was mainly Remain-supporting politicians who were at odds with constituency opinion (House of Commons 2016). The evidence presented here, however, suggests that this was not the case. In only 40 instances (out of 781) did a party pick a constituency candidate in 2017 who had voted differently at the EU referendum than its candidate in the same constituency had intended to do in 2015. Even more counter-intuitive is the fact that a Leave to Remain switch is more common than a Remain to

\footnotetext{
${ }^{18}$ In other words, we have information on the voting intention of party X candidate in constituency $\mathrm{Y}$ in 2015 as well as the voting choice of party X candidate in constituency Y in 2017. This would be the voting intention and voting choice of the exact same candidate if party X fielded the same candidate in constituency Y in 2015 and 2017, but it does not have to be. If party X fielded a different candidate in constituency Y in 2015 and 2017, the comparison would be between the voting intention and voting choice of these different candidates.
} 
Leave switch (22 versus 18), which suggests that there was no extensive effort from parties in 2017 to close the representation gap on the European issue. Instead, the story here is once again one of real stability. In the vast majority of instances - i.e., $94.9 \%$ (741 out of 781) - candidates who stood for election in 2017 cast the same EU referendum vote as those who ran in 2015 in the same constituency for the same party said they would. Taken together, the prevailing narrative is one of stability when it comes to the EU referendum position within the 'political class'.

[TABLE 4 HERE]

\section{Conclusions}

The 2016 EU referendum was one of the most divisive moments of the recent British political history. Not only did the electorate almost perfectly split between Leave and Remain, it also laid bare fundamental disagreements among politicians and political parties. It cost a premiership and helped a brand new political party win a national election. While we know quite a lot by now why some voters supported Leave, the evidence from the elite side is significantly scarcer.

This study uses data from the 2017 British Representation Study to address this lacuna. It explores the comparative relevance of different individual-level and contextual factors in motivating parliamentary candidates who stood at the 2017 general election to support, or oppose, Brexit in June 2016. We find Leave support to be higher among candidates who consider immigration-related issues to be the main problem facing the UK and are negative about the perceived cultural impact of immigration, who hold more positive expectations about the impact of Brexit on the UK's economy and democracy, and who are more critical about the state of democracy in the EU.

There are three broader points arising from this study and its findings. First, the evidence shown here reaffirms the prominent narrative in British politics, and society more broadly, that politicians are 'out of touch' with voters when it comes to their attitudes towards Leaving or Remaining. They are simply much less supportive of Brexit than the electorate as a whole. What the empirical evidence presented here adds to this widely accepted narrative is that this gulf is not just between voters and the political elites at the very top of the political ladder. We do not find systematic differences in the likelihood of incumbent MPs and challengers to support Leave. The latter include of course high-profile politicians such as former cabinet ministers and MPs, but most of them are not 'career politicians'. Most of them are councillors, business owners, entrepreneurs, academics, journalists, doctors, etc. who are active in their local party organisations and shape it on the local, grassroots level. This gulf in Leave support is not just between voters and the political elites, but voters and the 'political class' more broadly. 
Second, the findings suggest that support for, or opposition to, Leave is likely to be very stable among politicians. While we found Leave support to vary across politicians with contrasting political beliefs and perceptions of, among else, the state of democracy in the EU and the anticipated Brexit effect, the effect sizes associated with these explanatory factors are not huge. Gaining more information about what happens to the UK's economy post-Brexit, seeing the EU change how it operates, witnessing the impact that future immigration has on Britain, etc. are all likely to influence the level of Leave support among politicians, but any change is likely to be small. In fact, the comparison of survey data from the 2015 and 2017 general election lends further support to the notion that the prevailing narrative is one of stability when it comes to attitudes towards the EU within the 'political class'.

Third, the findings reveal some interesting differences as well as similarities between the motivations for Leave support among politicians and voters. Contrary to our expectations, and evidence from the voter literature, we do not find politicians' demographic characteristics to influence their likelihood of voting Leave. While socio-economic background and political attitudes are both found to shape Leave support among voters, we only find evidence for the relevance of the latter. Where our findings align with those from the voter side and with existing literature on the behaviour of parliamentarians is the comparative importance of different types of factors in explaining Leave vote. It is political opinions - e.g., views related to immigration, utilitarian considerations about the expected Brexit effect, and perceptions of how the EU works - that appear to be the main drivers of Leave vote among politicians as well as voters. This is also largely in line with existing literature on parliamentary behaviour, which shows that legislators' political views explain their voting on various issues (e.g., Cowley and Stuart 2012; Heppell et al. 2017; Jeffery et al. 2018). While politicians are indeed 'out of touch' with voters in terms of their likelihood of voting Leave, their key motivations for voting Leave are broadly in line with those among voters.

In summary, these findings broaden our understanding of who cast their ballot for Leave at the highly divisive $2016 \mathrm{EU}$ referendum. They build on the already extensive body of evidence from the voter side and explain what motivated political elites to vote for Leave. In doing so, these findings not only extend our understanding of Leave support within the 'political class', but they also allow for first-cut comparisons between the reasons that incentivised voters and politicians to cast their ballot for Leave. At the same time, this study leaves room and highlights the need for extending this research agenda. Future research should extend the range of explanatory factors used to explain Leave support among politicians and do so by focusing on politicians from a broader range of political parties. It should also examine support for Brexit exclusively among MPs who were successful at the 2019 general election to gain a better understanding of the motivations of politicians who will be in the heart of shaping the relationship between the UK and the EU and, ideally, do so in parallel to an identical analysis among voters to further address the 'out of touch' narrative. 


\section{Appendix A. 2017 British Representation Study}

The 2017 British Representation Study includes 872 candidates for whom information on all variables included in this study is available. We used the Duncan index of dissimilarity to show that this sample is broadly representative of the full population of the Conservative Party, the Green Party, the Labour Party, and the Liberal Democrats candidates in 2017. The index ranges from 0 to 1 , with higher values indicating greater discrepancy between the sample and the population (Duncan and Duncan 1955).

Table A1 shows the comparison between the sample used and the full population. The comparison of partisanship yields a value of 0.15 , the comparison of nation a value of 0.02 , and the comparison of electoral performance a value of 0.13 . The sample is broadly representative of the full population on these three key characteristics.

Table A1. 2017 British Representation Study sample

\begin{tabular}{|c|c|c|c|}
\hline & & Candidates $(\%)$ & Sample $(\%)$ \\
\hline \multicolumn{4}{|l|}{ Party } \\
\hline & Conservative Party & 26.9 & 12.0 \\
\hline & Green Party & 19.6 & 25.9 \\
\hline & Labour Party & 26.9 & 29.0 \\
\hline & Liberal Democrats & 26.8 & 33.0 \\
\hline & & \multicolumn{2}{|c|}{ Duncan index $=0.15$} \\
\hline
\end{tabular}

Nation

\begin{tabular}{rcr} 
England & 86.9 & 88.8 \\
Scotland & 7.7 & 6.2 \\
Wales & 5.5 & 5.1 \\
& \multicolumn{2}{c}{ Duncan index $=0.02$}
\end{tabular}

Electoral performance

\begin{tabular}{rrr} 
Successful & 25.2 & 12.4 \\
Unsuccessful & 74.8 & 87.6 \\
& \multicolumn{2}{c}{ Duncan index $=0.13$} \\
\hline
\end{tabular}




\section{Appendix B. Robustness check}

Table B1 presents findings from models that do not rely on the constant sample of candidates. That is, all candidates for whom information on the respective sub-sets of variables is available are included in the analysis. Estimates from these models are robust to those presented in Table 2.

Table B1. Explaining Leave vote using all available respondents

\begin{tabular}{|c|c|c|c|c|c|}
\hline & \multicolumn{5}{|c|}{ Leave vote } \\
\hline & Model B1 & Model B2 & Model B3 & Model B4 & Model B5 \\
\hline Gender & & $-0.24(0.30)$ & & & $0.17(0.44)$ \\
\hline Age & & $0.01(0.01)$ & & & $-0.01(0.02)$ \\
\hline Occupation & & $0.79(1.08)$ & & & $1.37(1.44)$ \\
\hline Incumbency & & $-0.09(0.37)$ & & & $0.18(0.54)$ \\
\hline Constituency vote & & & $0.03 * *(0.01)$ & & $0.02(0.01)$ \\
\hline MIP immigration & & & & $3.36 * *(0.74)$ & $3.28 * *(0.82)$ \\
\hline MIP economy & & & & $0.31(0.48)$ & $0.34(0.53)$ \\
\hline EU democracy & & & & $1.59 * *(0.37)$ & $1.76 * *(0.42)$ \\
\hline Immigration: economy & & & & $-0.23(0.15)$ & $-0.25(0.16)$ \\
\hline Immigration: cultural & & & & $-0.45^{* *}(0.13)$ & $\begin{array}{c}-0.46^{* *} \\
(0.14)\end{array}$ \\
\hline Brexit: economy & & & & $-0.73 * *(0.23)$ & $-0.63 *(0.25)$ \\
\hline Brexit: democracy & & & & $1.09 * *(0.28)$ & $1.11 * *(0.27)$ \\
\hline \multicolumn{6}{|l|}{ Party $^{\wedge}$} \\
\hline Green Party & $-3.30 * *(0.33)$ & $-3.10 * *(0.37)$ & $-3.41 * *(0.34)$ & $-0.02(0.52)$ & $-0.00(0.56)$ \\
\hline Labour Party & $-3.83 * *(0.38)$ & $-3.60 * *(0.40)$ & $-3.94 * *(0.39)$ & $-1.70 * *(0.51)$ & $\begin{array}{c}-1.64 * * \\
(0.54)\end{array}$ \\
\hline Liberal Democrats & $-4.74 * *(0.53)$ & $-4.59 * *(0.54)$ & $-4.85 * *(0.53)$ & $-1.17(0.65)$ & $-0.99(0.69)$ \\
\hline Constant & $0.21(0.17)$ & $-0.04(0.70)$ & $-1.55 *(0.61)$ & $-4.85 *(2.02)$ & $\begin{array}{c}-6.41 * * \\
(2.19)\end{array}$ \\
\hline Observations & 1,154 & 925 & 1,154 & 974 & 872 \\
\hline McFadden's R ${ }^{2}$ & 0.38 & 0.35 & 0.40 & 0.66 & 0.65 \\
\hline Log likelihood & -209 & -187 & -205 & -100 & -90 \\
\hline
\end{tabular}

Robust standard errors in parentheses; $* \mathrm{p}<0.05, * * \mathrm{p}<0.01$.

$\wedge$ Reference category is "Conservative Party". 


\section{References}

Allen, N. 2008. A New Ethical World of British MPs? The Journal of Legislative Studies 14/3: 297314.

Arnorsson, A. and Zoega, G. 2018. On the Causes of Brexit. European Journal of Political Economy 55/C: 301-323

Baughman, J. 2004. Party, Constituency, and Representation: Votes on Abortion in the British House of Commons. Public Choice 120/1: 63-85.

Becker, S.O., Fetzer, T. and Novy, D. 2017. Who Voted for Brexit? A Comprehensive District-Level Analysis. Economic Policy 32/92: 601-650.

Bromley-Davenport, H., MacLeavy, J. and Manley, D. 2018. Brexit in Sunderland: The Production of Difference and Division in the UK Referendum on European Union Membership. Environment and Planning C: Politics and Space OnlineFirst.

Buttice, M.K. and Milazzo, C. 2011. Candidate Positioning in Britain. Electoral Studies 30/4: 848857.

Campbell, R., Cowley, P., Vivyan, N. and Wagner, M. 2016. Legislator Dissent as a Valence Signal. British Journal of Political Science 49: 105-128.

Clarke, H.D., Goodwin, M. and Whiteley, P. 2017. Why Britain Voted for Brexit: An IndividualLevel Analysis of the 2016 Referendum Vote. Parliamentary Affairs 70/3: 439-464.

Colantone, I. and Stanig, P. 2018 Global Competition and Brexit. American Political Science Review 112/2: 201-218.

Cowley, P. and Stuart, M. 2010. Party Rues, OK: Voting in the House of Commons on the Human Fertilisation and Embryology Bill. Parliamentary Affairs 63/1: 173-181.

Crines, A. and Heppell, T. 2019. Legitimising Euroscepticism? The construction, delivery and significance of the Bruges speech. Contemporary British History doi:10.1080/13619462.2019.1669019.

Curtice, J. 2017. Why Leave Won the EU Referendum. Journal of Common Market Studies 55/S1: 19-37.

Daddow, O. 2013. Margaret Thatcher, Tony Blair and the Eurosceptic Tradition in Britain. The British Journal of Politics and International Relations 15: 210-227.

Duncan, O.D. and Duncan, B. 1955. A Methodological Analysis of Segregation Indexes. American Sociological Review 20/2: 210-217.

Evans, G., Fieldhouse, E., Green, J., Schmitt, H., van der Eijk, C., Mellon, J. and Prosser, C. 2016. British Election Study Internet Panel Wave 8 (2016 EU Referendum Study, Daily Campaign Survey). DOI: $10.15127 / 1.293723$.

Ford, R. and Goodwin, M. 2017. Britain after Brexit: A Nation Divided. Journal of Democracy 28/1: 17-30. 
Gamble, A. 2018. Taking Back Control: The Political Implications of Brexit. Journal of European Public Policy 25/8: 1215-1232.

Goodwin, M. and Heath, O. 2016. The 2016 Referendum, Brexit and the Left Behind: An AggregateLevel Analysis of the Result. The Political Quarterly 87/3: 323-332.

Goodwin, M. and Milazzo, C. 2017. Taking Back Control? Investigating the Role of Immigration in the 2016 Vote for Brexit. The British Journal of Politics and International Relations 19/3: 450-464.

Hanretty, C. 2017a. Areal Interpolation and the UK's Referendum on EU Membership. Journal of Elections, Public Opinion and Parties 27/4: 466-482.

Hanretty, C. 2017b. Final Estimates of the Leave Vote, or "Areal Interpolation and the UK's Referendum on EU Membership". Available: https://medium.com/@chrishanretty/finalestimates-of-the-leave-vote-or-areal-interpolation-and-the-uks-referendum-on-eumembership-5490b6cab878 (accessed 07 October 2019).

Hanretty, C., Lauderdale, B.E. and Vivyan, N. 2017. Dyadic Representation in a Westminster System. Legislative Studies Quarterly 42/2: 235-267.

Henderson, A., Jeffery, C., Liñeira, R., Scully, R., Wincott, D. and Wyn Jones, R. 2016. England, Englishness and Brexit. The Political Quarterly 87/2: 187-199.

Henderson, A., Jeffery, C., Wincott, D. and Wyn Jones, R. 2017. How Brexit Was Made in England. The British Journal of Politics and International Relations 19/4: 631-646.

Heppell, T. 2013. Cameron and Liberal Conservatism: Attitudes within the Parliamentary Conservative Party and Conservative Ministers. The British Journal of Politics and International Relations 15/3: 340-361.

Heppell, T., Crines, A. and Jeffery, D. 2017a. The United Kingdom Referendum on European Union Membership: The Voting of Conservative Parliamentarians. Journal of Common Market Studies 55/4: 762-778.

Heppell, T., Crines, A. and Jeffery, D. 2017b. The UK government and the $0.7 \%$ international aid target: Opinion among Conservative parliamentarians. The British Journal of Politics and International Relations 19/4: 895-909.

Hertner, I. and Keith, D. 2017. Europhiles or Eurosceptics? Comparing the European Policies of the Labour Party and the Liberal Democrats. British Politics 12/1: 63-89.

Hobolt, S. 2016. The Brexit Vote: A Divided Nation, a Divided Continent. Journal of European Public Policy 23/9: 1259-1277.

House of Commons. 2016. Brexit: The People vs. Parliament? Available: https://commonslibrary.parliament.uk/parliament-and-elections/parliament/brexit-the-peoplevs-parliament/ (accessed 07 October 2019). 
Jeffery, D., Heppell, T., Hayton, R. and Crines, A. 2018. The Conservative Party Leadership Election of 2016: An Analysis of the Voting Motivations of Conservative Parliamentarians.

Parliamentary Affairs 71: 263-282.

Johnston, R., Manley, D., Pattie, C. and Jones, K. 2018. Geographies of Brexit and its Aftermath: Voting in England at the 2016 Referendum and the 2017 General Election. Space and Polity 22/2: 162-187.

Jones, M. 2017. Wales and the Brexit Vote. Revue Française de Civilisation Britannique [Online]. DOI: $10.4000 /$ rfcb.1387.

Kam, C.J. 2009. Party Discipline and Parliamentary Politics. Cambridge: Cambridge University Press.

Lee, N., Morris, K. and Kemeny, T. 2018 Immobility and the Brexit Vote. Cambridge Journal of Regions, Economy and Society 11/1: 143-163.

Lynch, P. and Whitaker, R. 2018. All Brexiteers Now? Brexit, the Conservatives and Party Change. British Politics 13/1: 31-47.

MacLeod, G. and Jones, M. 2018. Explaining 'Brexit Capital': Uneven Development and the Austerity State. Space and Polity 22/2: 111-136.

Matti, J. and Zhou, T. 2017. The Political Economy of Brexit: Explaining the Vote. Applied Economics Letters 24/16: 1131-1134.

Mckenzie, L. 2017. 'It's not Ideal': Reconsidering 'Anger' and 'Apathy' in the Brexit Vote among an Invisible Working Class. Competition \& Change 21/3: 199-210.

Menon, A. and Salter, J-P. 2016. Brexit: Initial Reflections. International Affairs 92/6: 1297-1318.

Moore, L. 2018. Policy, Office and Votes: Conservative MPs and the Brexit Referendum. Parliamentary Affairs 71/1: 1-27.

Norris, P. and Lovenduski, J. 2004. Why Parties Fail to Learn: Electoral Defeat, Selective Perception and British Party Politics. Party Politics 10/1: 85-104.

PoliticsHome. 2016. MP Referendum Stance. Available: http://downloads2.dodsmonitoring.com/downloads/2016/EU2016/MPReferendumStance.xlsx (accessed 07 October 2019).

Shaw, D., Smith, C.M. and Scully, J. 2017. Why Did Brexit Happen? Using Causal Mapping to Analyse Secondary, Longitudinal Data. European Journal of Operational Research 263/3: 1019-1032.

Sobolewska, M., McKee, R. and Campbell, R. 2018. Explaining Motivation to Represent: How Does Descriptive Representation Lead to Substantive Representation of Racial and Ethnic Minorities? West European Politics 41/6: 1237-1261.

Tzelgov, E. 2014. Cross-Cutting Issues, Intraparty Dissent and Party Strategy: The Issue of European Integration in the House of Commons. European Union Politics 15/1: 3-23. 
Vasilopoulou, S. 2016. EU Euroscepticism and the Brexit Referendum. The Political Quarterly 87/2: 219-227.

Vasilopoulou, S. and Keith, D. 2019. Renegotiation versus Brexit: The Question of the UK's Constitutional Relationship with the EU. Journal of Common Market Studies 57/3: 486-501. Vasilopoulou, S. and Wagner, M. 2017. Fear, Anger and Enthusiasm about the European Union: Effects of Emotional Reactions on Public Preferences towards European Integration. European Union Politics 18/3: 382-405.

What UK Thinks. 2019. If There Was a Referendum on Britain's Membership of the EU, How Would You Vote? Available: https://whatukthinks.org/eu/questions/if-there-was-a-referendum-onbritains-membership-of-the-eu-how-would-you-vote-2 (accessed 07 October 2019). 


\section{Tables}

Table 1. Expectations

\begin{tabular}{lc}
\hline & Leave vote \\
\hline Gender & - \\
Age & + \\
Occupation & + \\
Incumbency & - \\
Constituency vote & + \\
MIP immigration & + \\
MIP economy & - \\
EU democracy & + \\
Immigration effect: economy & - \\
Immigration effect: cultural & - \\
Brexit effect: economy & - \\
Brexit effect: democracy & + \\
Party^ & - \\
\multicolumn{2}{c}{ Liberal Democrats } \\
\multicolumn{2}{c}{ Labour Party } \\
^ Reference category is "Conservative Party".
\end{tabular}

$\wedge$ Reference category is "Conservative Party". 
Table 2. Who voted Leave?

\begin{tabular}{|c|c|c|c|c|c|}
\hline & \multicolumn{5}{|c|}{ Leave vote } \\
\hline & Model 1 & Model 2 & Model 3 & Model 4 & Model 5 \\
\hline Gender & & $-0.38(0.33)$ & & & $0.17(0.44)$ \\
\hline Age & & $0.02(0.01)$ & & & $-0.01(0.02)$ \\
\hline Occupation & & $1.11(1.11)$ & & & $1.37(1.44)$ \\
\hline Incumbency & & $-0.31(0.38)$ & & & $0.18(0.54)$ \\
\hline Constituency vote & & & $0.03 *(0.01)$ & & $0.02(0.01)$ \\
\hline MIP immigration & & & & $3.24 * *(0.77)$ & $3.28 * *(0.82)$ \\
\hline MIP economy & & & & $0.34(0.51)$ & $0.34(0.53)$ \\
\hline EU democracy & & & & $1.72 * *(0.40)$ & $1.76 * *(0.42)$ \\
\hline Immigration: economy & & & & $-0.26(0.16)$ & $-0.25(0.16)$ \\
\hline Immigration: cultural & & & & $-0.44 * *(0.13)$ & $\begin{array}{c}-0.46^{* *} \\
(0.14)\end{array}$ \\
\hline Brexit: economy & & & & $-0.63 * *(0.24)$ & $-0.63 *(0.25)$ \\
\hline Brexit: democracy & & & & $1.10 * *(0.29)$ & $1.11 * *(0.27)$ \\
\hline \multicolumn{6}{|l|}{ Party $^{\wedge}$} \\
\hline Green Party & $-3.07 * *(0.37)$ & $-3.26 * *(0.40)$ & $-3.15^{* *}(0.37)$ & $0.05(0.55)$ & $-0.00(0.56)$ \\
\hline Labour Party & $-3.81 * *(0.46)$ & $-3.95 * *(0.47)$ & $-3.91 * *(0.47)$ & $-1.64 * *(0.51)$ & $\begin{array}{c}-1.64 * * \\
(0.54)\end{array}$ \\
\hline Liberal Democrats & $-4.36 * *(0.54)$ & $-4.58 * *(0.55)$ & $-4.46^{* *}(0.54)$ & $-1.04(0.67)$ & $-0.99(0.69)$ \\
\hline Constant & $0.10(0.20)$ & $-0.06(0.76)$ & $-1.39 *(0.65)$ & $-5.60 *(2.25)$ & $\begin{array}{c}-6.41 * * \\
(2.19)\end{array}$ \\
\hline Observations & 872 & 872 & 872 & 872 & 872 \\
\hline McFadden's $\mathrm{R}^{2}$ & 0.36 & 0.36 & 0.39 & 0.65 & 0.65 \\
\hline Log likelihood & -166 & -164 & -163 & -92 & -90 \\
\hline
\end{tabular}

Robust standard errors in parentheses; * $\mathrm{p}<0.05, * * \mathrm{p}<0.01$

$\wedge$ Reference category is "Conservative Party". 
Table 3. Predicted likelihood of voting Leave

\begin{tabular}{|c|c|}
\hline & Leave vote $(\%)$ \\
\hline \multicolumn{2}{|l|}{ MIP immigration } \\
\hline No & 8.6 \\
\hline Yes & 24.0 \\
\hline$\Delta$ & 15.4 \\
\hline \multicolumn{2}{|l|}{ EU democracy } \\
\hline Very satisfied & 0.8 \\
\hline Fairly satisfied & 2.5 \\
\hline Not very satisfied & 6.7 \\
\hline Not at all satisfied & 14.6 \\
\hline$\Delta$ & 13.8 \\
\hline \multicolumn{2}{|l|}{ Immigration: cultural } \\
\hline Undermines cultural life & 16.9 \\
\hline No effect & 10.2 \\
\hline Enriches cultural life & 5.7 \\
\hline$\Delta$ & 11.2 \\
\hline \multicolumn{2}{|l|}{ Brexit: economy } \\
\hline Businesses less likely to leave & 15.1 \\
\hline No effect & 9.6 \\
\hline Businesses more likely to leave & 5.7 \\
\hline$\Delta$ & 9.4 \\
\hline \multicolumn{2}{|l|}{ Brexit: democracy } \\
\hline Parliament will be weaker & 1.5 \\
\hline No effect & 5.4 \\
\hline Parliament will be stronger & 14.8 \\
\hline$\Delta$ & 13.3 \\
\hline
\end{tabular}


Table 4. EU referendum vote choice in 2015 and 2017

\begin{tabular}{lcc}
\hline & & Candidates \\
\hline Unchanged & & 363 \\
& Remain-> Remain & 67 \\
Leave->Leave & \\
& Remain->Leave & 7 \\
& Leave-> Remain & 5 \\
\hline Unchanged & & Parties* \\
& Remain->Remain & 656 \\
& Leave->Leave & 85 \\
Changed & & \\
& Remain->Leave & 18 \\
& Leave->Remain & 22 \\
\hline * Note: party
\end{tabular}

* Note: party candidate in the same constituency. 